\title{
KONSEP LIBASUTAQWA PADA PUSAT BUSANA MUSLIM SEBAGAI JAWABAN DI TRANSISI RUANG KOTA JAKARTA
}

\author{
${ }^{1}$ Fitri Sarah Maulani, ${ }^{2}$ Rita Laksmitasari Rahayu, ${ }^{3}$ M. Sega Sufia Purnama \\ ${ }^{1}$ Universitas Indraprasta PGRI, Program Studi Arsitektur \\ fsarahmaulani@gmail.com \\ ${ }^{2}$ Universitas Indraprasta PGRI, Program Studi Arsitektur \\ ritalaxmi@gmail.com \\ ${ }^{3}$ M.Sega Sufia Purnama \\ ${ }^{3}$ Universitas Indraprasta PGRI, Program Studi Arsitektur \\ Ages125@gmail.com
}

\begin{abstract}
Abstrak : Tujuan rancangan pusat busana muslim yaitu bangunan dengan standar rancangan secara berkualitas dan dapat menampung kapasitas pengguna dan pengunjung, memberikan fasilitas yang optimal serta menciptakan orientasi secara jelas serta fungsi dari bangunan pusat busana muslim, dan menghasilkan sarana bagi desainer fashion muslimah yang sesuai dengan syariat Islam yang sudah dijelaskan dalam Al-Quran. Pusat busana muslim direncanakan di wilayah Jakarta tepatnya di Jl. Mega Kuningan Timur Jakarta. Perancangan menggunakan konsep Libasutaqwa sesuai AlQur'an dan Hadist. Tema dikaji menggunakan nilai-nilai dasar dalam Al-Quran dan Hadist, serta syarat "Taqwa" dalam berpakaian. Karakteristik pakaian "Taqwa" diimplementasikan pada bangunan untuk mendapatkan karakteristik bangunan. Metodelogi perancangan ini menggunakan metodelogi deskriptif analisis data kualitatif. Proses perancangan pusat busana muslim, dengan mencari sumber dengan narasumber yang dibutuhkan dengan cara mewawancarai dan hasil pembahasan pada perancangan ini dapat menghasilkan fungsi serta fasilitas yang mewujudkan bangunan pusat busana muslim yang berkualitas serta eksklusif dengan standar rancangan.
\end{abstract}

Kata Kunci : Arsitektur Islam, Libasutaqwa, Transisi Ruang

\begin{abstract}
The purpose of this moeslim fashion centre design is a building with quality design standards and can accommodate the capasities of users and visitors, provide optimal facilities and create a clear orientation and funtions of the central building muslim fashion, and produce means explained in the muslim fashion centre in the Jakarta area right at Jl. Mega Kuningan East Jakarta. The design used the concept of Libasuttaqwa in accordance with the Al-Qur'an and the Hadith of Allah SW. The theme examined is using basic values in Al-Qur'an and Hadith, as well as the recuirements of Taqwa fashion characteristic. This methodelogy uses descriptive and qualitative analysis. The process of designing a muslim fashion centre, by searching for sources with the sources needed by interviewing and resultof discussions on the design of the gospel can produce fungtions and facilities that create quality fashion centre building and executive with design standards
\end{abstract}

Keyword : Islamic Architecture, Libasutaqwa, Space Transition

\section{PENDAHULUAN}

Banyak masyarakat membutuhkan busana muslimah sebagai kebutuhan pokok yang harus dipenuhi. Seiring berkembangnya gaya hidup di dunia fashion, trend busana muslimah sangat mewarnai ranah fashion busana di Indonesia. Trend busana muslimah berkembang dengan pesat dari tahun ke tahun yang disesuaikan dengan selera masyarakat. Saat ini muslimah milenial cenderung dengan topik hijrah. Kecenderungan tersebut menjadi trend busana muslim. Banyak event bermunculan untuk menjawab kebutuhan busana muslimah yang berkualitas, salah satunya adalah fashion weeks
Jakarta. Berdasarkan hal tersebut dibutuhkan suatu wadah yang dapat menampung para desainer khususnya desainer muda. Seorang muslim menggunakan pakaian yang sudah ditentukan dalam Al-Quran dan Hadist. Adapun kandungan Al-Quran sudah menjelaskan tentang berpakaian atau berbusana dalam islam yaitu menutup aurat. Berikut ini penjelasan ayat Qur'an tentang menutup aurat dengan pakaian.

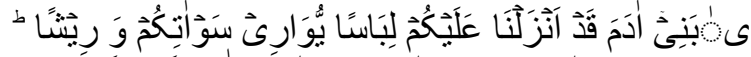

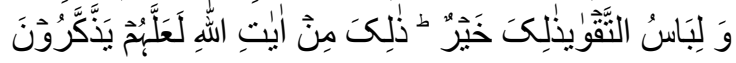

(QS.Al-A'raaf/7:26) 
Artinya : Wahai anak cucu Adam! Sesungguhnya Kami telah menyediakan pakaian untuk menutupi auratmu dan untuk perhiasan bagimu. Tetapi pakaian takwa, itulah yang lebih baik. Demikianlah sebagian tanda-tanda kekuasaan Allah, mudah-mudahan mereka ingat. (QS.AlA'raaf/7:26)

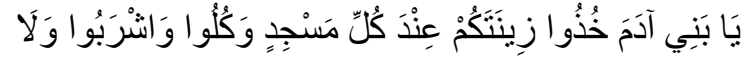

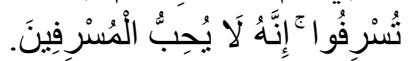

(QS. Al-A'raf Ayat 31)

Artinya : Hai anak Adam, pakailah pakaianmu yang indah di setiap (memasuki) mesjid, makan dan minumlah, dan janganlah berlebih-lebihan. Sesungguhnya Allah tidak menyukai orang-orang yang berlebih-lebihan. (QS. Al-A 'raf Ayat 31)

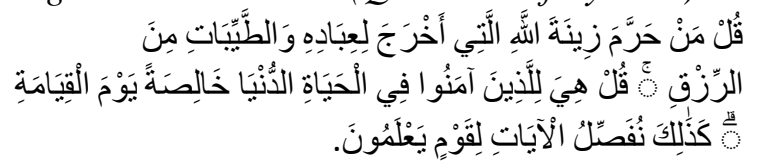

Artinya : Katakanlah: "Siapakah yang mengharamkan perhiasan dari Allah yang telah dikeluarkan-Nya untuk hamba-hamba-Nya dan (siapa pulakah yang mengharamkan) rezeki yang baik?" Katakanlah: "Semuanya itu (disediakan) bagi orang-orang yang beriman dalam kehidupan dunia, khusus (untuk mereka saja) di hari kiamat". Demikianlah Kami menjelaskan ayat-ayat itu bagi orang-orang yang mengetahui. (QS. Al-A'raf Ayat 32).

Perancangan ini menggunakan pendekatan dan konsep Arsitektur Islam. Pendekatan dan konsep desain bangunan menciptakan suatu rancangan sesuai dengan prinsip-prinsip pada arsitektur islam yaitu: Habluminallah, Habluminannas, Habluminal'alam sebagai landasan perancangan Arsitektur Islam (Jamal junaid, 2010).

Definisi dari pusat busana muslim dengan beberapa definisi yaitu : mengemukakan bahwa Butik adalah suatu usaha pembuatan busana dengan jahitan kualitas tinggi dengan penjualan pelengkap busananya. (Arifah A. Riayanto. 2003:120)

Definisi busana muslim merupakan busana yang berfungsi sebagai penutup aurat dan berfungsi sebagai penunjang penampilan dan keindahan dalam berbusana atau berpakaian. Busana muslim merupakan busana yang mengikut aturan norma agama Islam. Dalam ajaran Islam busana tidak hanya semata-mata masalah budaya dan mode. Islam menetapkan batasan-batasan tertentu untuk laki-laki maupun perempuan. Untuk perempuan, memiliki busana khusus yang menunjukkan identitasnya sebagai seorang muslimah serta dapat dijadikan sebagai simbol kehormatan, kesederhaan dan dapat melindungi dari berbagai bahaya yang mungkin mengacam dirinya.

\section{METODOLOGI}

Metode perancangan ini menggunakan metode deskriptif analisis data kualitatif.

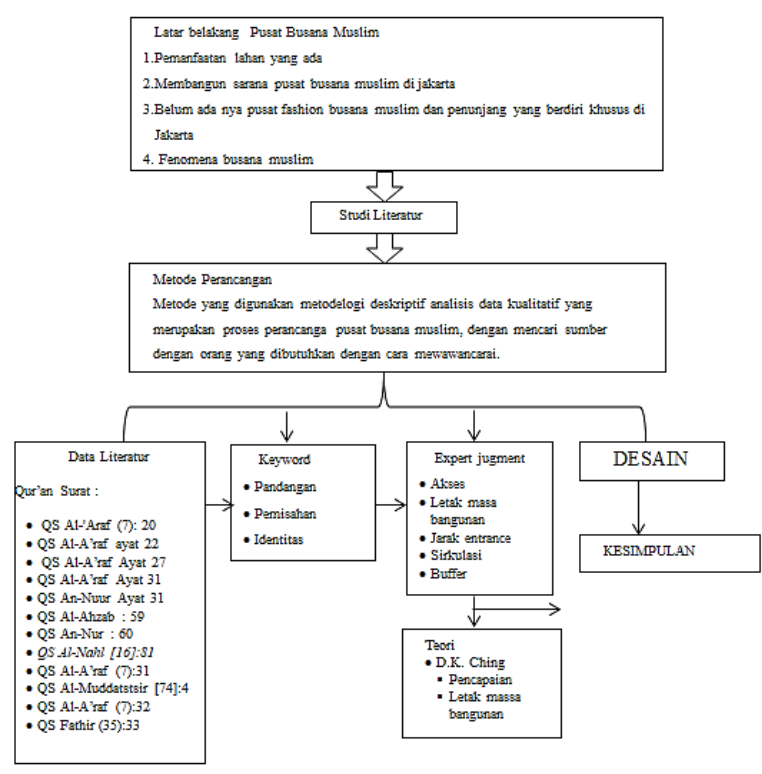

Bagan 1. Alur Proses Perancangan

Kerangka pada perancangan pusat busana muslim ini yaitu :

a. Identifikasi Masalah

1. Lokasi site berlokasi di Jl. Kuningan Raya, Setia Budi, Jakarta selatan. Site ini memiliki kekurangan yakni ada nya fly over atau jalan layang

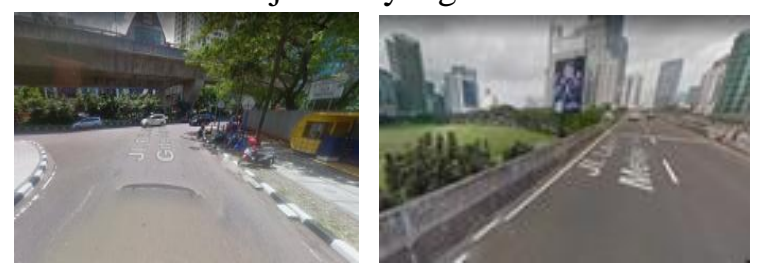

Gambar 1: view pada site

2. Dijelaskan dalam Al-Qur'an bagaimana cara berpakaian seorang muslim serta 
tentang kewajiban kaum muslim khususnya untuk menutup aurat dan terlindungi dari segala yang membahayakan diri.

3. Penulis melihat fenomena atau issue yang sedang terjadi tentang berbusana muslim yang saat ini menjadi trend dan membantu bagi yang baru mengenakan busana muslim, serta fenomena banyak yang mentransisi pola kehidupan menjadi lebih baik( hijrah).

4. Belum adanya pusat busana muslim yang menjadikan pusat serta wadah bagi desainer muda saat ini yang bergabung dalam sebuah gedung yang sama

b. Pengumpulan Data

1) Studi Literarur

Sebuah studi literatur diperoleh dari media massa, media online, jurnal, buku, dan lainnya. Hasil pengamatan tidak langsung untuk memeroleh data dan berbagai informasi yang berkaitan dengan permasalahan dan persoalan tentang desain yang dibutuhkan.

2) Studi banding

Survey langsung ke lapangan dengan melakukan pengamatan di beberapa butik. Survey dilakukan untuk melihat kondisi yang sebenarnya dan dapat menghasilkan bahan data yang akurat

\section{HASIL DAN PEMBAHASAN}

Proses dari perancangan melingkupi konsep Libasutaqwa pakaian yang disebut libasut taqwa yang berarti pakaian yang merupakan ketakwaan, yang menyelamatkan diri, menyegarkan jiwa, membangkitkan budi pekerti dan akhlak yang mulia. Pakaian inilah yang menjamin keselamatan diri, dunia dan akhirat, menjamin kebahagiaan rumah tangga dan menjamin keamanan serta ketentraman dalam masyarakat dan negara. Dari konsep Libasutaqwa dapat diimplementasikan melalui beberapa aspek untuk hasil terhadap bangunan tersebut,

Transisi dari konsep Libasutaqwa yang berkaitan dengan peralihan atau perbedaan dalam suatu ruang, dan tempat yang berbeda fungsi, perbedaan ruang dapat menggunakan pembatas ruang yang memiik fungsi yang berbeda tetapi di suatu ruang yang sama, dengan menggunakan pembatas reeling, contoh pada perancangan ini pusat busana muslim untuk ruang desainer terdapat ruang fitting room tanpa menggunkan pembatas permanen, melainkan dengan menggunkan relling sebgai pembatas. Pada sebuah bangunan ruang ataupun elemen dengan peralihan suatu bangunan sangat mempengaruhi untuk keseluruhan ruang bangunan tersebut. Terkait dengan konsep Libasutaqwa pada pusat busana muslim di jakarta memiliki jawaban dengan adanya fashion centre yang berbeda serta pusat busana muslim ini memiliki fasilitas untuk menunjukan peragaan busana serta memiliki konsep mecerminkan seorang wanita yang menutup aurat dengan penuh tetapi dapat memiliki pandangan yang eksklusif serta memiliki image sebagai wanita muslimah yang elegan.

Table 1. Implementasi Desain

\begin{tabular}{|c|c|c|}
\hline No. & Syarat pakaian libasutaqwa & Implementasi desain \\
\hline 1 & $\begin{array}{l}\text { Mentupi seluruh tubuh kecuali } \\
\text { syariat } \\
\text { Terdapatpada QS. An-Niur } \\
\text { Ayat } 31\end{array}$ & $\begin{array}{l}\text { - Membedakan event wanita dengan event laki-laki } \\
\text { - Kenyamanan bagipengguna bangunan } \\
\text { - Memberikan shading device( secondary skin), fasa dagar } \\
\text { meminimalkan cahaya sinarmataharilangsungmasuk }\end{array}$ \\
\hline 2 & $\begin{array}{l}\text { Tidak tembus pandang atau } \\
\text { transparanterdapat pada dalam } \\
\text { sebuah Hadist yang } \\
\text { diriwayatkan oleh imam } \\
\text { Muslim dalam kitabnya Shohih } \\
\text { Muslim/2128 }\end{array}$ & $\begin{array}{l}\text { - Pemisahan area showroomwanita } \\
\text { - Membedakan ruang ganti wanita } \\
\text { - Menerapkan ruangan yangmempunyai void pa dainterior } \\
\text { sebagai pelapis atau pemb atas untuk merju uruang butik } \\
\text { atau showroom } \\
\text { - Memberikan ruanghij au untukmencapai bangunan utama } \\
\text { sebagairuang tunggu outdoor } \\
\text { - Peletakanmassa bangunanpa dajarak dari entrance gate } \\
\text { - Pencapaianmenujuarea bangunan memberikan vegetasi } \\
\text { atau buffer untuk meminimalkan pandanganlangsung }\end{array}$ \\
\hline 3 & $\begin{array}{l}\text { Tidak menyerupaipakaian orang } \\
\text { kafir ataunonmuslim } \\
\text { Q.S. Al Hadid: } 16\end{array}$ & $\begin{array}{l}\text { - Penyesuaian sirkulasi yang efisien, sehingga memudahkan } \\
\text { aktifitas pengurjumg } \\
\text { - Penyesuaian sirkulasi antara pengurijung wanita dan laki- } \\
\text { laki } \\
\text { - Penyesuaianjenis vegetasi } \\
\text { - Penyesuaian fasad bangunanyang sederhana sehingga tida } \\
\text { berlebihan }\end{array}$ \\
\hline 4 & $\begin{array}{l}\text { Tidak ketat atautidak } \\
\text { memperlihatkan bentuk lekukan } \\
\text { tubuh } \\
\text { Di niwayatkan oleh H.R. Ahmad }\end{array}$ & $\begin{array}{l}\text { - Tidak memperlihatkan atau dapat meminimalkan bentuk } \\
\text { bangunan dan bentukpada dasar denah yang tidak } \\
\text { memiliki banyak lekukN } \\
\text { - Membedakan ruangan publik dengan privasi }\end{array}$ \\
\hline 5 & $\begin{array}{l}\text { Tidak berfungsi sebagai } \\
\text { perhiasan terdapat paada QS. Al- } \\
\text { Ahzab cyat } 33 \\
\text { - Memiliki rasa aman dan } \\
\text { nyaman } \\
\text { - Terhindar darikejahatan serta } \\
\text { melindungi dir sendin } \\
\end{array}$ & $\begin{array}{l}\text { - Menerapkan beberapa alata atau bahan penghias ataujenis } \\
\text { vegetasi serta berfungsi sebagai penetralisir kebisingan } \\
\text { danijalan utama danjalanarea bangunan }\end{array}$ \\
\hline 6 & $\begin{array}{l}\text { Tidak terlalu berlebihan atau } \\
\text { mewah diriwayatkan oleh H.R. } \\
\text { Abu Dawud dan Ibn Majah }\end{array}$ & $\begin{array}{l}\text { - Menerpkanbengunan dengan bertukyang tidak } \\
\text { berlebihan sehingga terkesan sederhana tetapi memiliki } \\
\text { nilai yangindah } \\
\text { - Menerpakan fasad pada tampak bangunan yang memiliki } \\
\text { image libassuta qwa, sederhana tetapi sesuai syariat } \\
\text { libassuta quva }\end{array}$ \\
\hline
\end{tabular}

Serta untuk mendapatkan sebuah bentuk melalu beberapa bentuk dasar yaitu bentuk pada bangunan pusat busana muslim. Konsep Libasutaqwa yang diterapkan tidak memliki bentuk yang berlebihan dari bentuk bangunan, 
fasad bangunan serta bentuk denah. Bentuk dasar yang dibuat yaitu persegi menjadi bentuk awal yang mengikuti dari teori DK.Ching

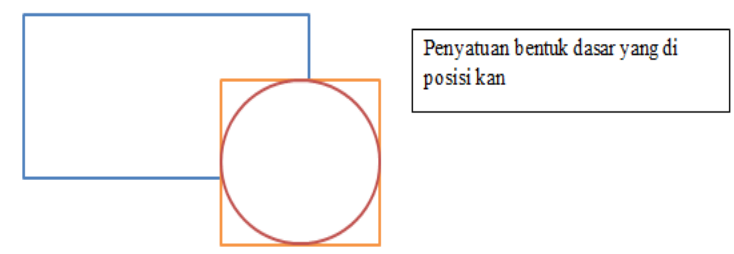

Gambar 2. Bentuk Denah

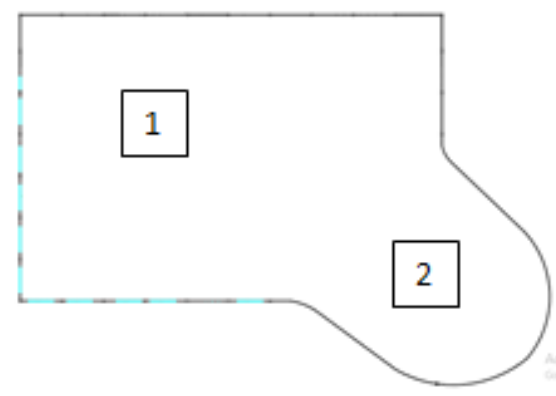

Gambar 3. Hasil desain site plan

Dari bentuk dasar, desain di tranformasikan pada denah perancangan pusat busana muslim. Perancangan desain ini mengakomodasi kebutuhan dan prinsip desain secara arsitektur Konsep Libasutaqwa dengan proses yang diusung dari ayat Al-Qur'an yang dapat di implementasikan dalam bentuk bangunan yang mengikuti syarat berpakaian muslimah.

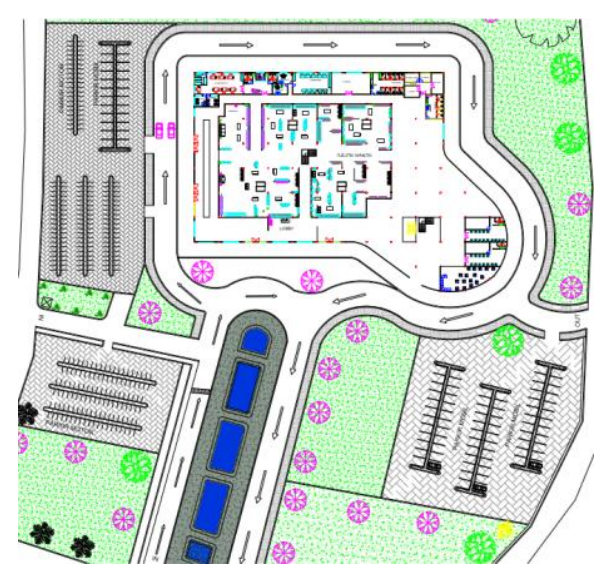

Gambar 4. Denah lantai 1

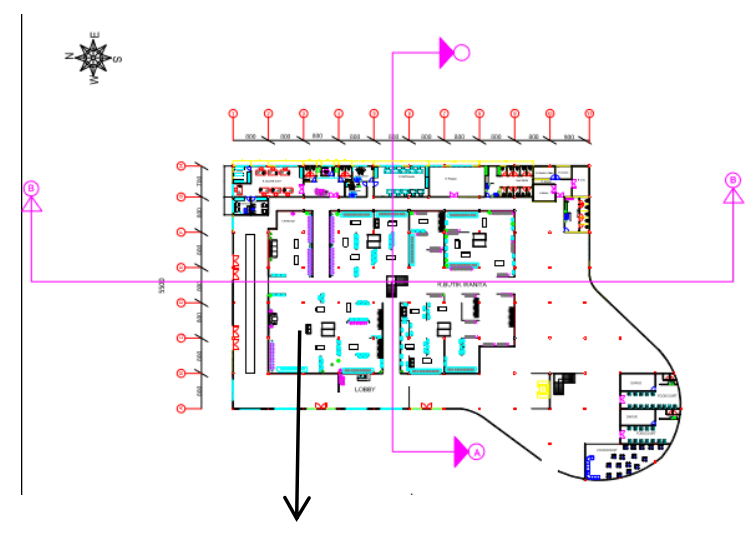

Gambar 4. Denah lantai 2

Untuk hasil desain pada denah ini memakai konsep syarat berpakaian seorang muslim khususnya Muslimah yang merupakan aurat wajib ditutup. Tidak tembus pandang yang membahayakan, dan diimplementasikan pada suatu ruangan galeri pusat busana muslim.

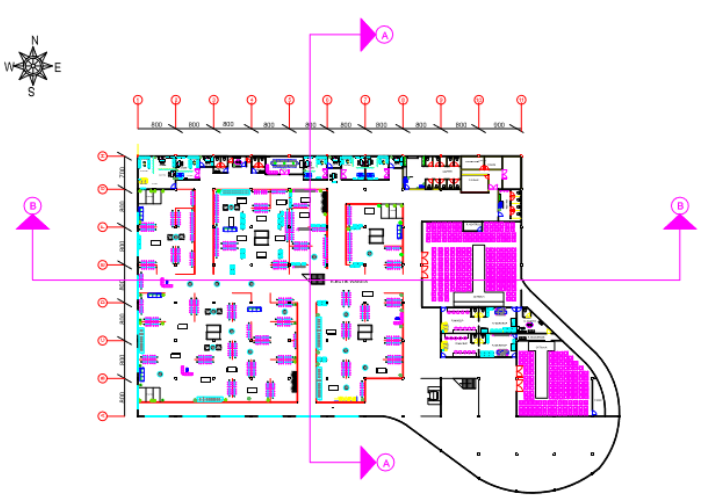

Gambar 5. Eksterior pusat busana muslim

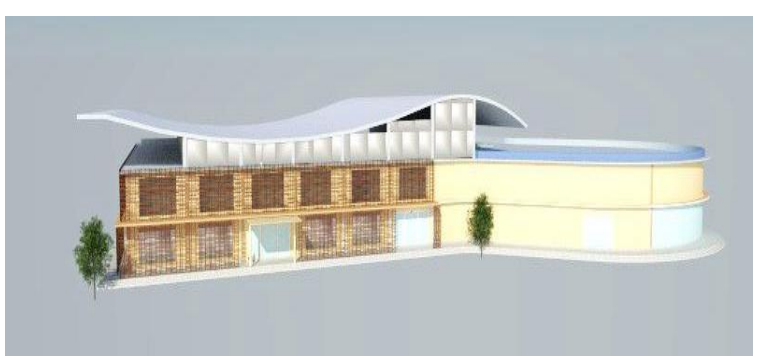

Gambar 6. Eksterior pusat busana muslim

Dan pada eksterior bangunan memakai sun shading untuk meminimalisir cahaya yang masuk secara langsung yang dapat merusak koleksi busana yang ada. 


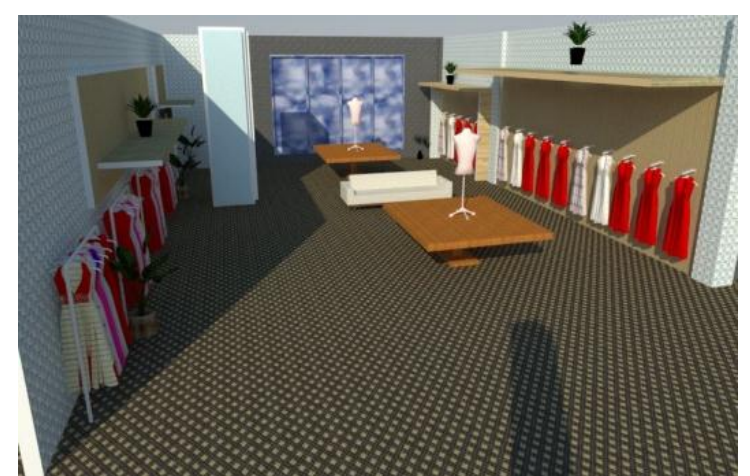

Gambar 7. Interior Pusat Busana muslim

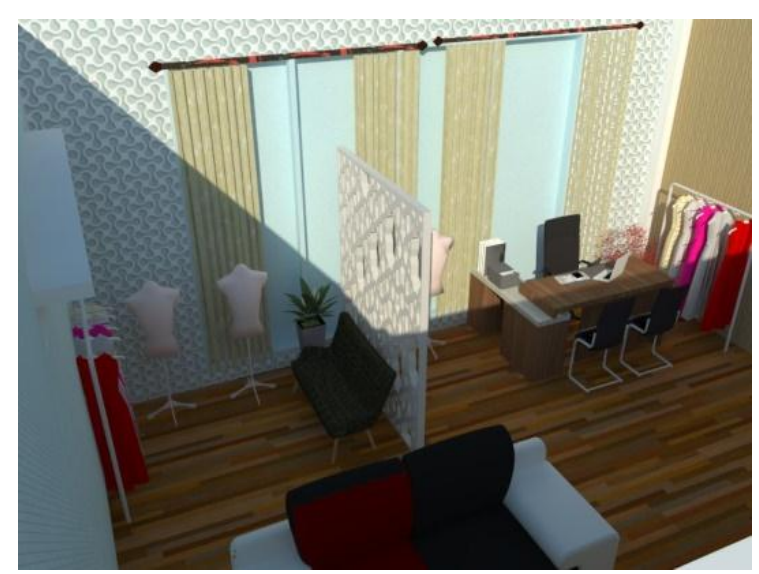

Gambar 8. Interior ruangan designer

\section{PENUTUP}

\section{Simpulan}

Simpulan dari pembahasan rancangan yang menghasilkan perancangan ini dilakukan dari berbagai solusi arsitektural yang mengikuti Al-Qur'an dan Hadist Allah SWT, dengan tema Arsitektur Islam Libasutaqwa. Tema yang dipilih berdasarkan pertimbangan dan nilai-nilai keislaman yang mampu dikaitkan dengan objek perancangan sehingga objek tersebut dapat bermanfaat bagi masyarakat muslim di Jakarta maupun di luar Jakarta. Dengan menciptakan sebuah fungsi dan fasilitas yang mampu memenuhi kebutuhan masyarakat umum dan awam dengan skala pelayanan kelas menengah atas dan konteks sebuah butik ekslusif

\section{Saran}

Dalam perancangan pusat busana muslim banyak hal yang belum terpenuhi dari aspek aspek yang didapat, dan dari itu perlu kajian yang lebih lanjut terkait dengan perancangan ini, perancangan yang diharapkan mampu memberikan manfaat bagi para pembaca dalam meningkatkan perkembangan dunia fashion busana muslim, dan mempermudah aktivitas di dalam sebuah bangunan, serta memberikan alternatif penyelesaian desain dengan cara menggunakan konsep arsitektur islam yang berkaitan dengan Libasutaqwa dalam mewujudkan pada bangunan tersebut

\section{DAFTAR PUSTAKA}

Poerwadarminta. W.J.S. 2003. Kamus Umum Bahasa Indonesia. Jakarta : Balai. Pustaka.

Jamal junaid, (2010). Konsep Arsitektur Islami sebagai solusi dalam perancangan : Yogyakarta. Journal of Islamic Architecture Volume 1 Issue June 2010.

Poerwadarminta. W.J.S. 2003. Kamus Umum Bahasa Indonesia. Jakarta : Balai. Pustaka.

Riyanto, A (2003). Desain Busana. Bandung: Yapendo.

Ernawati, dkk.(2008). Tata Busana, Jilid 1 untuk Sekolah Menengah Kejuruan. Jakarta : Direktorat Pembinaan Sekolah Menengah Kejuruan

Al-Qur'an dan Terjemhannya QS. Al-A'raf Ayat 26, Departemen Agama. Republik Indonesia, Proyek Pengadaan Kitab Suci Al-Qur'an, Jakarta

Al-Qur'an dan Terjemhannya QS. Al-A'raf Ayat 31-32, Departemen Agama. Republik Indonesia, Proyek Pengadaan Kitab Suci Al-Qur'an.

Francis, D.K Ching Arsitektur, Bentuk, Ruang, dan Susunannya. Erlangga, Jakarta, 1993. 